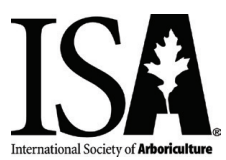

\title{
Ten-Year Performance of the United States National Elm Trial
}

\author{
Jason J. Griffin, William R. Jacobi, E. Gregory McPherson, Clifford S. Sadof, \\ James R. McKenna, Mark L. Gleason, Nicole Ward Gauthier, Daniel A. Potter, \\ David R. Smitley, Gerard C. Adams, Ann Brooks Gould, Christian R. Cash, \\ James A. Walla, Mark C. Starrett, Gary Chastagner, \\ Jeff L. Sibley, Vera A. Krischik, and Adam F. Newby
}

\begin{abstract}
Ulmus americana (American elm) was an important urban tree in North America prior to the introduction of the Dutch elm disease pathogen in 1930. Subsequently, urban and community forests were devastated by the loss of large canopies. Tree improvement programs produced disease tolerant American and Eurasian elm cultivars and introduced them into the nursery industry. However, consumer acceptance was slow. The National Elm Trial was established to evaluate commercially available taxa of elm across the United States. Established at 16 locations, these plantings monitored survival and growth, as well as disease and insect pressure for 7 to 10 years. 'Morton' elm had $>90 \%$ survival, while 13 cultivars averaged $70 \%$ to $90 \%$, and five cultivars ranged from $25 \%$ to $69 \%$ survival. Trunk diameter growth by location ranged from $0.5 \mathrm{~cm} / \mathrm{year}$ (Colorado, U.S.) to more than $2.0 \mathrm{~cm}$ /year (Iowa, U.S.). By taxa, trunk diameter growth ranged from a low, by 'JFS Bieberich' elm (0.7 $\mathrm{cm} /$ year), to a high by 'New Horizon' elm (1.7 cm/year). Scale insects were minor issues at most trial locations, except Colorado, where scales contributed to the death of several cultivars. Performance ratings (scale 1 to 5 ) ranged from 2.7 for 'JFS Bieberich' elm to 4.5 for 'New Horizon' elm. Based on the ratings, the preferred cultivars of American elm were 'New Harmony' and 'Princeton', and the preferred cultivars of Asian elm were The Morton Arboretum introductions and 'New Horizon'. These findings will help green-industry professionals determine what elm cultivars will perform the best in different regions.

Key Words. Chalkbark Elm; Japanese Elm; Lacebark Elm; Scotch Elm; Siberian Elm; Smoothleaf Elm; Tree Evaluation; Ulmus carpinifolia; Ulmus glabra; Ulmus japonica; Ulmus parvifolia; Ulmus propinqua; Ulmus pumila; Ulmus wilsoniana; Urban Forestry; Wilson Elm.
\end{abstract}

American elm is commonly found in soils that are saturated in spring and autumn; however, it also grows well in deep soils with good drainage. The root system is generally considered shallow but will develop deeper in dry sites with good soil drainage (Harlow et al. 1991). The tall trees with broad, arching branches were a favorite of landscape developers and were once the predominant landscape and street tree across the United States (Gerhold et al. 1993; Plotnik 2000). American elm can tolerate many urban conditions, including soil compaction, flooding, air pollution, and deicing salts (Townsend 2000). Additionally, the species is easy to propagate, grow, and transplant.

In the early 1930s, the introduction of Dutch elm disease (DED) forced the green industry to abandon
American elm for more disease-resistant exotic species and encouraged plant breeders to search for or develop disease-resistant elms. The result of many decades of intentional and opportunistic selection has been a rather broad selection of Asian, American, and European species and hybrid elms with various degrees of resistance to DED (Santamour and Bentz 1995; The Morton Arboretum 2015).

\section{Diseases and Insects of Elms}

The common diseases of elm (Ulmus) in North America include DED, elm yellows (elm phloem necrosis) and bacterial leaf scorch, bacterial wet wood, and various root, canker, and foliar diseases (Stipes and Campana 1981; Sinclair and Lyon 2005). DED is a vascular wilt disease incited by the exotic 
fungi Ophiostoma ulmi and O. novo-ulmi. These pathogens move among trees via elm bark beetle vectors and by root grafts (Lanier 1981; Peacock 1981; Webber and Gibbs 1989; Vega and Blackwell 2005). Elm phloem necrosis is widely distributed throughout the eastern portion of the United States (Sinclair and Lyon 2005; Martin 2012). The disease is caused by phytoplasmas (usually 'Candidatus Phytoplasma ulmi') that are vectored by leafhoppers and spittlebugs (Karnosky 1982; Riffle and Peterson 1986). Elm phloem necrosis kills phloem tissue in roots and stems, causing death one to two years after symptoms appear (Sinclair and Lyon 2005; Martin 2012). Visual symptoms are similar to DED and the disease may be misidentified by casual inspection. Currently, all North American native elm species are affected, and there are no known preventative or curative treatments (Riffle and Peterson 1986; Martin 2012). Bacterial leaf scorch (Xylella fastidiosa) is predominately found in eastern North America, but it is not known as a limiting factor in the use of elm.

Root decay diseases of elm include Armillaria, Ganoderma, Inonotus, and Laetiporus decays that are occasional issues in the eastern half of North America (Sinclair and Lyon 2005). Cankers are common on Asian varieties in environmentally stressful sites, including Cytospora (Cytospora spp.), black spot Nectria (Nectria nigrescens, anamorph Tubercularia ulmea), and Siberian elm/Botryodiplodia canker (Botryodiplodia hypodermia). Black leaf spot (Stegophora ulmea, formerly Gnomonia ulmea) is the most common leaf spot on American elm cultivars in moist areas of North America. Black leaf spot symptoms include small, black, slightly raised, spots (Sinclair and Lyon 2005).

There are several insect pests that can cause damage to elms (Dirr 2009), and most of the major damaging insects were introduced to North America. Insect pests include various defoliators, leafminers, twig girdlers, bark beetles, borers, and numerous scales and aphids that produce honeydew and resulting sooty mold (Condra et al. 2010; Potter and Redmond 2013). The most common defoliators include Japanese beetle (Popillia japonica), gypsy moth (Lymantria dispar), elm leaf beetle (Xanthogaleruca luteola), and European elm flea weevil (Orchestes alni), all of which can cause unsightly damage to the crown (Condra et al. 2010; Potter and Redmond 2013). Defoliators are gener- ally considered a nuisance, since their populations fluctuate, and even though they can cause enough damage to make elm crowns aesthetically unappealing, they do not normally cause enough damage to kill portions of a tree. However, they can be lethal when combined with other plant stressors. Breeding efforts have been moderately successful incorporating elm leaf beetle feeding resistance into some hybrids (Townsend 2000). European elm scale (Ericoccus spuria) is an introduced and very damaging scale insect that causes branch dieback and can cause great concern from the abundant honeydew production and resultant sooty mold growing on plant and hard surfaces below infested trees.

\section{Breeding and Selection for Resistance to Dutch Elm Disease}

Breeding and screening efforts for DED-resistant elms began in the 1930s shortly after the disease was introduced (Townsend and Douglass 2001; Mittempergher and Santini 2004). However, it was the 1970s before efforts at various institutions made significant progress (Townsend 2000). Major elm improvement programs were conducted in Wisconsin, Illinois, Ohio, New York, Washington, D.C., and Maryland, U.S. (Smalley and Guries 1993; Mittempergher and Santini 2004; Townsend et al. 2005). Initial breeding efforts and cultivar releases were based on European and Asian species of elm, because of their inherent resistance to DED (Townsend and Schreiber 1975; Smalley and Guries 1993; Townsend 2000; Townsend and Douglass 2004). Those efforts resulted in the release of several cultivars of elm: 'Urban', 'Dynasty', 'Homestead', 'Pioneer', 'Frontier', 'Prospector', 'Ohio', 'Pathfinder', and 'Patriot' (Townsend 2000).

The development of DED-resistant American elm was slower due to the high mortality rate of seedlings when inoculated with the disease (Smalley and Guries 1993; Mittempergher and Santini 2004). For example, the initial USDA screening of more than 35,000 American elm seedlings for DED tolerance yielded only two trees worthy of further testing (Townsend 2000; Mittempergher and Santini 2004). One of those was subsequently named 'Delaware', and was used to successfully incorporate some level of DED tolerance to progeny (Townsend et al. 2005). Townsend and Schreiber (1975) noted good segregation among progeny for disease resistance and growth char- 
acteristics. After screening numerous seedlings and survivor/escape trees in areas with high DED pressure, American elms with varying levels of disease resistance began to surface. Trees with potential resistance were propagated, field planted, and inoculated with the causal fungus of DED (Townsend et al. 1995; Townsend and Douglass 2001; Townsend et al. 2005). Symptoms of DED and crown dieback were recorded over time. The extent of crown dieback was compared to known susceptible American elm seedlings and known resistant Asian hybrids.

Two early selections of American elm ('Valley Forge' and 'New Harmony') are grown commonly at the time of this writing. 'Princeton' American elm was selected by Princeton Nurseries in 1922 (prior to the introduction of DED) for its narrow growth habit and rapid growth rate (Townsend et al. 2005). Time has shown it to be DED-tolerant and a popular landscape tree. It should be noted that 'Valley Forge', 'Princeton', and 'New Harmony' selections have shown excellent tolerance to DED over the years but not complete resistance (Townsend et al. 1995; Townsend and Douglass 2001; Townsend et al. 2005). Even in inoculation tests, the data suggests that 'Valley Forge' still shows a very low level of susceptibility. 'American Liberty' elm ( $U$. americana) was another early release reported to be resistant to DED. However, inoculation studies later determined it sustained crown dieback similar to American elm seedlings (Townsend et al. 1995; Townsend and Douglass 2001; Costello et al. 2004). By the mid-1990s, American elms with reported DED tolerance were undergoing extensive field testing and were then later released (Townsend et al. 1995). Breeding, screening, and selection of American elms with DED tolerance and improved growth habits continues with a goal of increasing the genetic diversity of DED-tolerant elms (Slavicek and Knight 2011).

\section{National Elm Trial}

The National Elm Trial was initiated because, in light of the success of DED resistance in American elms, there remains a lack of awareness or lack in confidence among green-industry professionals and the general public in these trees. The National Elm Trial (CSU 2017) was a volunteer education and outreach effort to evaluate the use of commer- cially available DED-resistant and DED-tolerant elms. The trial was developed by the NCR-193 Agricultural Experiment Station coordinating committee on insects and diseases of woody ornamentals. American, European, Asian, and hybrid elms were included. Trial sites were established across the United States in a variety of growing conditions and USDA hardiness zones where the general public and green-industry professionals could have easy access to the plantings. Individual evaluation plantings were maintained by local research and extension personnel located at land grant universities, colleges, and research stations (Table 1; Table 2 ; Figure 1). The trial also benefited from generous industry support and knowledge (Table 3).

The study objectives were to 1 ) determine the growth and horticultural performance of commercially available DED-resistant and DEDtolerant elm cultivars in various climate regimes in the United States; 2) determine the relative disease, insect, and abiotic stress tolerance of these cultivars; and 3) relate the results of the trial through local, regional, and national reporting to wholesale tree propagators and growers, retail nursery and garden center operators, landscape designers, arborists, and the general public.

\section{MATERIALS AND METHODS}

Fourteen to eighteen taxa of elm were planted in 16 locations in the United States (Table 1; Table 2; Figure 1). The cultivars represented a range of hybrids and species of Ulmus and were chosen based on their commercial availability (Table 3). Some cooperators incorporated other cultivars of elm of local interest into their planting, and the performance data of these taxa are available in the state reports on the National Elm Trial website (CSU 2017).

Trees were produced by commercial nurseries on their own roots (rooted cuttings or from tissue culture) or budded onto seedling U. pumila (Siberian elm) rootstocks (Table 3). Bare root trees, $1.5-1.8 \mathrm{~m}$ in height, were shipped by nurseries to cooperator sites for planting beginning spring 2005. Due to inventories, availability, and establishment failure, some selections were planted in subsequent years (Table 2).

Planting was done according to local recommendations and site cooperator's preference. Irrigation and vegetation management was 
determined by the local cooperator in accordance with need and common local standards (Table 3). All locations used mowing to manage weed and grass between tree rows, and most locations used chemical weed management for a $0.5 \mathrm{~m}$ weed free circle around each tree. All trees in all blocks were treated similarly within a site. Data was collected annually by the site coordina- tor. This data included stem diameter at $1.37 \mathrm{~m}$ above the ground (dbh), tree height, crown width in the row, autumn color, occurrence of insects and diseases, and an overall performance/quality rating. The subjective performance/quality rating ( $1-5$ scale; 1 = poor, $2=$ fair, $3=$ good, 4 $=$ very good, and $5=$ excellent) of the cultivars incorporated survival, growth rate, branching

Table 1. Location, climate characteristics, and management of U.S. National Elm Trial sites (2005-2015).

\begin{tabular}{|c|c|c|c|c|c|c|c|c|c|}
\hline State & City & $\begin{array}{l}\text { Year } \\
\text { planted }^{z}\end{array}$ & $\begin{array}{l}\text { Data } \\
\text { year }^{y}\end{array}$ & $\begin{array}{l}\text { Hardiness } \\
\text { zone }^{x}\end{array}$ & $\begin{array}{l}\text { Heat } \\
\text { zone }^{w}\end{array}$ & $\begin{array}{l}\text { Ave. annual } \\
\text { precip. }(\mathrm{cm})^{\mathrm{v}}\end{array}$ & $\begin{array}{l}\text { Supplemental } \\
\text { irrigation }\end{array}$ & $\begin{array}{l}\text { Grass } \\
\text { management }^{\mathrm{u}}\end{array}$ & $\begin{array}{l}\text { Weed } \\
\text { control }^{t}\end{array}$ \\
\hline $\mathrm{CO}$ & Fort Collins & 2005 & 2014 & $5 b$ & 7 & 38.0 & $\mathrm{Y}$ & mowed & $\mathrm{Y}$ \\
\hline IN & W. Lafayette & 2005 & 2014 & $5 b$ & 6 & 93.0 & $\mathrm{~N}$ & mowed & $\mathrm{N}$ \\
\hline IA & Ames & 2005 & 2013 & $5 a$ & 5 & 88.1 & $\mathrm{~N}$ & mowed & $\mathrm{Y}$ \\
\hline KY & Lexington & 2005 & 2012 & $6 \mathrm{~b}$ & 6 & 114.7 & $\mathrm{~N}$ & mowed & $\mathrm{Y}$ \\
\hline MI & East Lansing & 2005 & 2014 & $5 b$ & 4 & 81.7 & $\mathrm{Y}$ & mowed & $\mathrm{N}$ \\
\hline NJ & Cream Ridge & 2005 & 2014 & $7 \mathrm{a}$ & 5 & 124.3 & $\mathrm{~N}$ & mowed & $\mathrm{N}$ \\
\hline NY & Cobleskill & 2005 & 2013 & $5 b$ & 4 & 97.8 & $\mathrm{~N}$ & mowed & $\mathrm{N}$ \\
\hline ND & Fargo & 2005-2008 & 2015 & $4 \mathrm{a}$ & 5 & 63.6 & $\mathrm{~N}$ & mowed & $\mathrm{N}$ \\
\hline ND & Bismarck & $2005-2008$ & 2015 & $4 a$ & 5 & 45.6 & $\mathrm{~N}$ & not mowed & $\mathrm{N}$ \\
\hline VT & Burlington & 2005 & 2015 & $5 a$ & 4 & 95.5 & $\mathrm{~N}$ & mowed & $\mathrm{N}$ \\
\hline WA & Puyallup & 2005 & 2013 & $8 b$ & 3 & 102.7 & $\mathrm{~N}$ & mowed & $\mathrm{Y}$ \\
\hline WV & Morgantown & 2005 & 2013 & $6 b$ & 5 & 109.6 & $\mathrm{~N}$ & mowed & $\mathrm{N}$ \\
\hline $\mathrm{AL}$ & Auburn & 2007 & 2014 & $8 a$ & 8 & 133.5 & $\mathrm{~N}$ & mowed & $\mathrm{N}$ \\
\hline KS & Haysville & 2007 & 2014 & $6 \mathrm{~b}$ & 8 & 91.3 & $\mathrm{Y}$ & mowed & $\mathrm{N}$ \\
\hline $\mathrm{MN}$ & St. Paul & 2004-2007 & 2015 & $4 b$ & 4 & 81.0 & $\mathrm{~N}$ & mowed & $\mathrm{N}$ \\
\hline $\mathrm{OH}$ & Columbus & 2005 & 2014 & $6 a$ & 5 & 99.0 & $\mathrm{~N}$ & mowed & $\mathrm{N}$ \\
\hline
\end{tabular}

${ }^{z}$ Due to lack of availability, not all sites were planted with all cultivars the same year.

$\mathrm{y}$ The final year data was collected for analysis and this report.

$x$ (USDA 2012)

w (AHS 2017)

v (NOAA 2017)

"Vegetation under the tree canopies within the plot was either allowed to grow naturally (not mowed) or mowed to control growth.

${ }^{t}$ Herbicides used to control vegetation immediately surrounding the tree trunk.

Table 2. Cooperators and locations of U.S. National Elm Trials.

\begin{tabular}{|c|c|c|c|c|c|c|}
\hline Cooperator & Organization & City/State & Planting year & Data year & Email & Phone number \\
\hline Dr. W.R. Jacobi & Colorado State Univ. & Fort Collins/CO & 2005 & 2014 & william.jacobi@colostate.edu & $970-491-6927$ \\
\hline Dr. J. Klett & Colorado State Univ. & Fort Collins/CO & & & jim.klett@colostate.edu & $970-491-7179$ \\
\hline Dr. C. Sadof & Purdue University & W. Lafayette/IN & 2005 & 2014 & csadof@purdue.edu & $765-494-5983$ \\
\hline Mr. J.R. McKenna & USDA For. Serv. & W. Lafayette/IN & & & jrmckenn@purdue.edu & \\
\hline Dr. M. Gleason & Iowa State Univ. & Ames/IA & 2005 & 2013 & mgleason@iastate.edu & 515-294-0579 \\
\hline Dr. N. Ward Gauthier & Univ. of Kentucky & Lexington/KY & 2005 & 2012 & nicole.ward@uky.edu & $859-218-0720$ \\
\hline Dr. D. Potter & Univ. of Kentucky & Lexington/KY & & & dapotter@uky.edu & $859-257-7458$ \\
\hline Dr. D. Fulbright & Michigan State Univ. & East Lansing/MI & 2005 & 2014 & fulbrig1@msu.edu & $517-819-1043$ \\
\hline Dr. D. Smitley & Michigan State Univ. & East Lansing/MI & 2005 & & smitley@msu.edu & $517-355-3385$ \\
\hline Dr. A. Brooks Gould & Rutgers University & New Brunswick/NJ & 2005 & 2014 & gould@aesop.rutgers.edu & $848-932-6398$ \\
\hline Mr. C. Cash & SUNY Cobleskill & Cobleskill/NY & 2005 & 2015 & cashc@cobleskill.edu & $518376-2657$ \\
\hline \multirow[t]{2}{*}{ Dr. J. Walla } & Northern Tree & Fargo and Bismarck/ & 2005 & 2015 & northerntrees@outlook.com & $701-235-5454$ \\
\hline & Specialties & $\mathrm{ND}$ & 2008 & & & \\
\hline \multirow[t]{2}{*}{ Mr. A. Bergdahl } & N.D. State For. Serv. & Fargo and Bismarck/ & 2005 & 2015 & aaron.d.bergdahl@ndsu.edu & $701-231-5138$ \\
\hline & & ND & 2008 & & & \\
\hline Dr. M. Starrett & Univ. of Vermont & Burlington/VT & 2005 & 2015 & mark.starrett@uvm.edu & $802-656-0467$ \\
\hline Dr. M. Elliot & Wash. State Univ. & Puyallup/WA & 2005 & 2013 & melliott2@wsu.edu & \\
\hline Dr. G. Chastagner & Wash. State Univ. & Puyallup/WA & & & chastag@wsu.edu & $253-445-4528$ \\
\hline Dr. M. Kasson & West Virginia Univ. & Morgantown/WV & 2005 & 2013 & mtkasson@mail.wvu.edu & $304-293-8837$ \\
\hline Mr. M. Double & West Virginia Univ. & Morgantown/WV & 2005 & 2013 & mdouble@wvu.edu & $304-293-9277$ \\
\hline Dr. J. Sibley & Auburn Univ. & Auburn/AL & 2007 & 2014 & sibleje@auburn.edu & $334844-3132$ \\
\hline Dr. A. Newby & Auburn Univ. & Auburn/AL & & & newbyaf@auburn.edu & $334-844-3034$ \\
\hline Dr. J. Griffin & Kansas State Univ. & Haysville/KS & 2007 & 2014 & jgriffin@ksu.edu & $316788-0492$ \\
\hline \multirow[t]{3}{*}{ Dr. V. Krischik } & Univ. of Minnesota & St. Paul/MN & 2004 & 2015 & krisc001@umn.edu & $612-625-7044$ \\
\hline & & & 2007 & & & \\
\hline & Columbus Parks & Columbus/OH & 2005 & 2015 & & \\
\hline
\end{tabular}


Table 3. Taxa and nursery supplier of elms planted in the U.S. National Elm Trial 2005-2015.

\begin{tabular}{|c|c|c|c|c|}
\hline Cultivar name & $\begin{array}{l}\text { Trademarked or } \\
\text { registered name }\end{array}$ & Parentage & Originator $^{z}$ & Supplier ${ }^{y}$ \\
\hline 'Lewis \& Clark'x & Prairie Expedition & U. americana & NDSU & LN \\
\hline 'New Harmony'x & & U. americana & USDA & PN \& SNA \\
\hline 'Princeton'x & & U. americana & $\mathrm{PN}$ & PN \& SNA \\
\hline 'Valley Forge'x & & U. americana & USDA & JFS \\
\hline 'Frontier'x & & U. carpinifolia $\times U$. parvifolia & USDA & JFS \\
\hline 'Morton Stalwart'w & Commendation & $\begin{array}{l}U . \text { carpinifolia } \times U . \text { pumila } \times \\
U . \text { wilsoniana }\end{array}$ & MA & JFS \\
\hline 'Pioneer'x & & U. glabra $\times U$. carpinifolia & USDA & JFS \\
\hline 'Homestead'x & & $\begin{array}{l}\text { U. glabra } \times U . \text { carpinifolia } \times \\
U . \text { pumila }\end{array}$ & USDA & JFS \\
\hline 'Patriot'x & & $\begin{array}{l}(U . \text { glabra } \times U . \text { carpinifolia } \times \\
U . \text { pumila }) \times U . \text { wilsoniana }\end{array}$ & USDA & JFS \\
\hline 'Morton'w & Accolade & U. japonica $\times U$. wilsoniana & MA & JFS \\
\hline 'Morton Red Tip'w & Danada Charm & U. japonica $\times U$. wilsoniana & MA & JFS \\
\hline 'Emer I’x & Athena Classic & U. parvifolia & UGA & BSN \\
\hline 'Emer II’v & Allee & U. parvifolia & UGA & JFS \\
\hline 'BSNUPF’x & Everclear & U. parvifolia & $\mathrm{BSN}$ & BSN \\
\hline 'JFS-Bieberich'w & Emerald Sunshine & U. propinqua & SNA & JFS \\
\hline 'Morton Plainsman'w & Vanguard & U. pumila $\times U$. japonica & MA & JFS \\
\hline 'New Horizon'w & & U. pumila $\times$ U. japonica & UW & JFS \\
\hline 'Morton Glossy'w & Triumph & $\begin{array}{l}U . \text { pumila } \times U . \text { japonica } \times \\
U . \text { wilsoniana }\end{array}$ & MA & JFS \\
\hline 'Prospector'x & & U. wilsoniana & USDA & JFS \\
\hline
\end{tabular}

${ }^{\text {z }}$ Organization responsible for discovery: MA = The Morton Arboretum; BSN = Bold Spring Nursery Inc.; USDA = United States Department of Agriculture; UW = University of Wisconsin; SNA = Sunshine Nursery \& Arboretum; UGA = University of Georgia; PN = Princeton Nurseries; NDSU = North Dakota State University. ${ }^{y}$ Nursery that provided bare-root plants for National Elm Trial: JFS = J. Frank Schmidt \& Son Co.; BSN = Bold Springs Nursery Inc.; PN = Princeton Nurseries; LN $=$ Lee Nursery Inc.; SNA = Container grown, Sunshine Nursery \& Arboretum, KS only.

${ }^{x}$ Own-root rooted cutting.

${ }^{\text {w }}$ Budded to U. pumila (Siberian elm) rootstock.

${ }^{v}$ Own-root tissue culture.

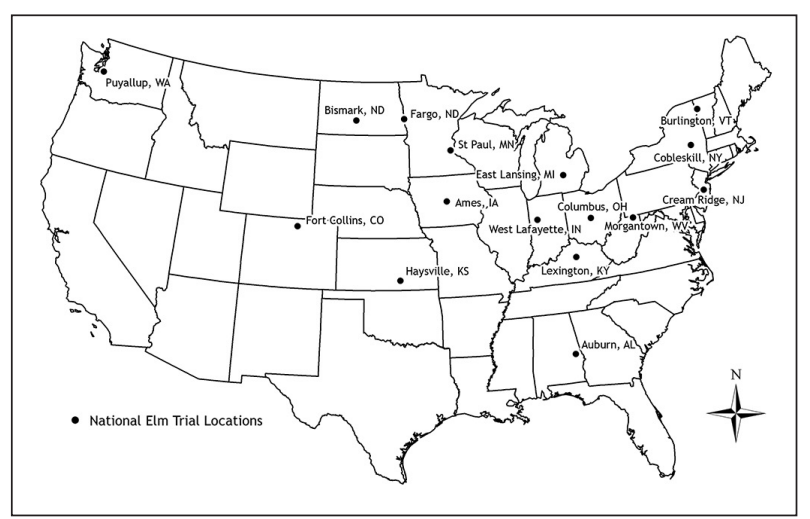

Figure 1. Location of sixteen National Elm Trial sites (20052015) across the continental United States.

patterns, form, and insect and disease damage. Each site had their own evaluator conduct the performance/quality rating at the conclusion of the project. The experimental design was a randomized complete block design with five blocks, each containing one individual of each cultivar.

All data were collected in a similar manner at all locations; summary statistics were prepared using SAS/STAT $^{\circledast}$ software (Version 9.4, SAS Institute Inc., Cary, North Carolina, U.S.). Proc GLM was used to prepare least square means of diameter, height, and crown width growth, as well as insect, disease, and overall quality ratings (1-5), taking into account state as a fixed effect variable. There was a small but significant $(P=0.001)$ state-bycultivar interaction that was ignored in an effort to compare cultivar means over all states. When diameter growth was presented by state, cultivar was the fixed effect. Growth rates per year were calculated from the difference between final data collection and initial data collected at planting because not all cooperators collected data annually. Data from West Virginia (WV) was excluded from the analysis because cultivar growth at that location was inconsistent with the remaining sites. Also excluded were data from cultivars planted at only one or two sites [U. $\times$ 'Cathedral', U. parvifolia 'Dynasty' (lacebark elm), U. $\times$ 'Regal', U. japonica 'Discovery' (Japanese elm), U. americana 'Kuhar II', and U. rubra (red elm)]. Three cultivars of U. parvifolia ('BSNUPF', 'Emer I' and 'Emer II') were not sufficiently represented (not planted or failed to survive) to provide data in the analysis to produce least square means displayed in Figure 2 through Figure 8. Cultivar performance at each state location is available at the National Elm Trial website (CSU 2017). 


\section{RESULTS AND DISCUSSION}

\section{Overall Trial Success}

Elm cultivars were planted over a wide geographic range (Figure1). Trial locations had a variety of soils, the average annual precipitation ranged from $\approx 0.4 \mathrm{~m}$ at Colorado $(\mathrm{CO})$ to $\approx 1.3$ at Alabama (AL), and USDA Plant Hardiness Zones (USDA 2012) ranged from Zone $4 \mathrm{a}$ in North Dakota (ND) to Zone 9b in California (CA) (Table 1). The American Horticultural Society Heat Zone map (AHS 2017) was also referenced, since summer heat plays a significant role in plant growth, as well as humidity and irrigation requirements. Trial site Heat Zones ranged from Zone 3 in Washington (WA) to Zone 8 in AL, CA, and Kansas (KS). Due to individual site environmental characteristics, cultural practices were at the discretion of the site coordinator. For example, some sites were irrigated for two years to establishment while other were irrigated to prevent excessive summer desiccation. Year-to-year weather variation also influenced cultural practices. In KS, for instance, trees were irrigated bi-weekly during the historic heat wave and droughts of summers 2011 and 2012 to prevent death. However, trees were not irrigated after 2012 and were irrigated only twice per summer prior to 2011. Nearly all sites chose to mow the vegetation within the trial plot, and used herbicides to keep the area surrounding the tree trunk weed free. At most locations, trees were allowed to grow without major structural pruning. Minor pruning was needed to lift the crowns for maintenance and to restore a central leader, if needed. In a typical urban or landscape environment, however, structural pruning will be required on many elms. Co-dominant leaders, narrow branch angles, and excessive shoot growth are negative attributes common among some cultivars of elm that need to be corrected with pruning.

Data were obtained from all sites with the exception of CA, which terminated the study early. Therefore, data from CA were omitted from tables and figures. Results from the first two years at CA can be found in an earlier report (McPherson et al. 2009). The growing conditions at each site are not necessarily representative of growing conditions throughout the region or every region throughout the United States. Therefore, while elm performance at a particular site is useful and informative, it does not necessarily represent how the cultivars will perform in all sites in that region. For example, the extremely slow trunk diameter growth of elms in the CO study does not indicate an overall lack of elm adaptability in other parts of CO. Instead, it indicates elm growth was influenced by the compacted clay soils coupled with irrigation challenges (Figure 2). Additionally, the poor overall survival of trees in WV does not suggest elms should not be planted in that region. Most tree deaths in the WV study occurred from deer browsing prior to the installation of fencing. Additionally, not all states or regions of the United States were represented in the trial. Readers are encouraged to use this information and consult with local experts when contemplating planting elm trees.

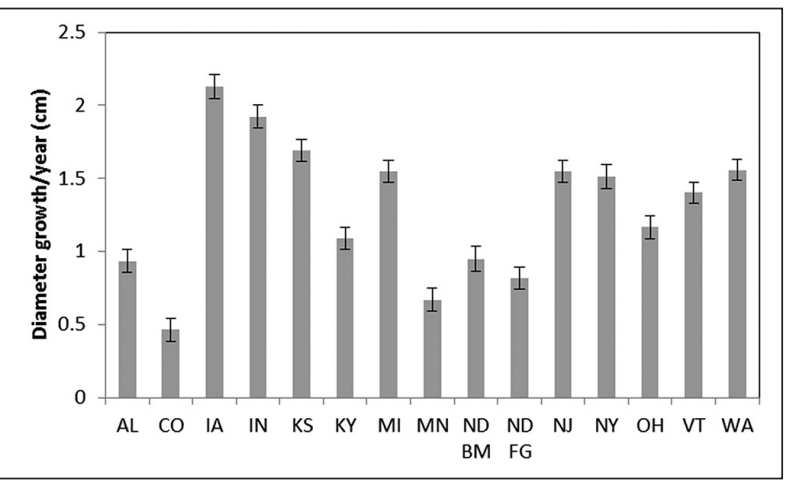

Figure 2. Average trunk diameter growth (dbh) per year (cm), with standard-error bars, of all elm cultivars by state, U.S. National Elm Trial 2005-2015. Least square means were adjusted to account for cultivar variation.

\section{Cultivar Survival}

Most cultivars grew and survived under the varied growing conditions of the 16 trial sites (Table 4). Only one cultivar, 'Morton' elm, had an average survival $>90 \%$, with a survival rate of $100 \%$ at 13 trial sites. Only Iowa (IA), ND, and WV reported two dead 'Morton' elms at each site. These three locations also had the three lowest overall mean survival rates across all cultivars (51\%, 56\%, and $45 \%$, respectively), suggesting environment, culture, or a combination were unfavorable for the elms. Seven cultivars, including two American elms ('New Harmony' and 'Princeton') and five hybrid Asian elm selections ('Morton Stalwart', 'Pioneer', 
'Homestead', 'Patriot', and 'Morton Glossy') averaged $80 \%-89 \%$ survival. Six Asian hybrids or species ('Frontier', 'Morton Red Tip', 'JFS Bieberich', 'Morton Plainsman', 'New Horizon', and 'Prospector') had 70\%-79\% survival. Two American elms ('Lewis \& Clark' and 'Valley Forge') were in the $60 \%-69 \%$ survival group. Both of these cultivars were produced on their own roots from rooted cuttings. Liners of American elms produced from cuttings often have tall vigorous shoots with disproportionally small root systems. These cultivars were no exception at planting (personal observation). This root/shoot imbalance may have resulted in some water deficit stress for these cultivars, thereby lowering their overall survival. The remaining three cultivars in the lowest survival group of $25 \%-59 \%$ were selections of lacebark elm. These cultivars were not planted at many sites, and most were killed by freeze damage. However, the lower survival rate at milder sites could simply be a result of fewer plants or poor performance at the limited number of sites.

Of the four American elm cultivars, 'New Harmony' and 'Princeton' had the greatest survival rate at $85.5 \%$ and $81.5 \%$, respectively. 'Lewis \& Clark' and 'Valley Forge' had a lower survival rate at $63.6 \%$ and $66.7 \%$ survival, respectively. The
'Lewis \& Clark' elm is relatively new (as of this writing) and less known by the nursery and landscape industries. Due to difficulty in sourcing plant material, this cultivar was planted in only 11 of the 16 locations. Limited trial sites and poor performance at three sites may have unfairly influenced the survival rating. The 'Valley Forge' elm is very well-known and is considered a fast grower with exceptional DED resistance. Overall survival is not considered a weakness of this cultivar. Again, poor performance at five of the fifteen sites may have biased the data against this tree. Lacebark elm is a staple of the nursery industry in the southern half of the United States. Cold hardiness has been an issue in recommending this tree in northern climates. The poor performance of lacebark elm, particularly in sites with cold winters, was expected. However, 100\% survival of 'Emer I' elm in Michigan (MI) was not expected. Similarly, $80 \%$ survival of 'BSNUPF' elm in Vermont (VT) is interesting.

\section{Cultivar Growth}

Average trunk diameter growth (dbh) of all cultivars combined per site varied from less than 0.5 $\mathrm{cm} /$ year at $\mathrm{CO}$ to more than $2.0 \mathrm{~cm} /$ year at IA (Figure 2). Trees at CO and WV had such poor growth that those sites would not provide rea-

Table 4. Survival (\%) of elm cultivars planted in 16 U.S. National Elm Trial locations (2005-2015).

\begin{tabular}{|c|c|c|c|c|c|c|c|c|c|c|c|c|c|c|c|c|c|}
\hline \multirow[t]{2}{*}{ Cultivar name } & \multicolumn{3}{|c|}{ Western states } & \multicolumn{6}{|c|}{ Central states } & \multicolumn{7}{|c|}{ Eastern states } & \multirow[t]{2}{*}{ Mean } \\
\hline & WA & $\mathrm{CO}$ & KS & IA & $\mathrm{NDF}^{z}$ & $\mathrm{NDB}^{\mathrm{y}}$ & $\mathrm{MN}$ & MI & IN & $\mathrm{AL}$ & NY & $\mathrm{NJ}$ & VT & $\mathrm{OH}$ & WV & KY & \\
\hline \multicolumn{18}{|l|}{ American selections } \\
\hline 'Lewis \& Clark' & $100^{\mathrm{x}}$ & 0 & 80 & 40 & 40 & 100 & 80 & 40 & - & 60 & - & - & 80 & - & - & 80 & 63.6 \\
\hline 'New Harmony' & 100 & 100 & 100 & 80 & 100 & 20 & - & 100 & - & - & - & 100 & 100 & - & 40 & 100 & 85.5 \\
\hline 'Princeton' & 100 & 100 & 100 & 80 & 100 & 0 & 100 & 100 & 20 & 80 & - & 80 & 100 & - & - & 100 & 81.5 \\
\hline 'Valley Forge' & 100 & 40 & 100 & 0 & 80 & 0 & 100 & 60 & 40 & - & 80 & 100 & 100 & 100 & 20 & 80 & 66.7 \\
\hline \multicolumn{18}{|l|}{ Asian selections } \\
\hline 'Frontier' & 100 & 40 & 100 & 40 & 14 & 20 & - & 80 & 100 & 100 & 100 & 100 & 100 & 100 & 20 & 100 & 74.3 \\
\hline 'Morton Stalwart' & 100 & 100 & 60 & 80 & 100 & 100 & 100 & 80 & 80 & 100 & 100 & 100 & 80 & 100 & 20 & 60 & 85.0 \\
\hline 'Pioneer’ & 80 & 100 & 100 & 80 & 75 & 80 & 100 & 60 & 80 & 60 & 100 & 100 & 80 & 100 & 80 & 20 & 81.0 \\
\hline 'Homestead' & 80 & 100 & 100 & 80 & 100 & 60 & 100 & 100 & 40 & 80 & 100 & 80 & 100 & 100 & 40 & 100 & 85.0 \\
\hline 'Patriot' & 100 & 40 & 100 & 80 & 100 & 60 & 80 & 100 & 100 & 100 & 100 & 100 & 100 & 100 & 60 & 40 & 85.0 \\
\hline 'Morton' & 100 & 100 & 100 & 60 & 100 & 60 & 100 & 100 & 100 & 100 & 100 & 100 & 100 & 100 & 60 & 100 & 92.5 \\
\hline 'Morton Red Tip' & 100 & 80 & 100 & 0 & 100 & 100 & 80 & 60 & 60 & 100 & 100 & 60 & 60 & 100 & 40 & 100 & 77.5 \\
\hline ‘Emer I’ & - & 0 & - & - & - & - & - & 100 & - & 60 & - & & - & - & - & 60 & 55.0 \\
\hline ‘Emer II’ & 40 & 0 & 80 & 0 & - & - & 20 & 0 & 20 & 40 & 0 & 0 & 0 & 20 & 80 & 60 & 25.7 \\
\hline ‘BSNUPF’' & - & 0 & - & - & - & - & - & 20 & - & 80 & - & & 80 & - & - & 40 & 44.0 \\
\hline 'JFS Bieberich' & 100 & 0 & 80 & 40 & 0 & 20 & 80 & 100 & 100 & 100 & 80 & 100 & 100 & 100 & 40 & 80 & 70.0 \\
\hline 'Morton Plainsman' & 100 & 80 & 80 & 100 & 40 & 80 & 100 & 80 & 60 & 60 & 80 & 100 & 100 & 75 & 40 & 80 & 78.4 \\
\hline 'New Horizon' & 20 & 40 & 100 & 0 & 40 & 100 & 100 & 100 & 80 & 80 & 80 & 100 & 100 & 100 & 40 & 100 & 73.8 \\
\hline 'Morton Glossy' & 100 & 80 & 100 & 100 & 60 & 100 & 100 & 20 & 100 & 80 & 100 & 100 & 100 & 100 & 60 & 80 & 86.2 \\
\hline 'Prospector' & 80 & 100 & 100 & 0 & 40 & 0 & 100 & 100 & 100 & 80 & 100 & 100 & 100 & 100 & 40 & 80 & 76.2 \\
\hline
\end{tabular}

${ }^{2}$ Fargo, North Dakota, U.S.

y Bismarck, North Dakota, U.S.

${ }^{x}$ Mean of five, single-plant replicates per location. 
sonable information on cultivar performance in regards to growth, shape, or form (Figure 2). Trees at CO did not grow well because of extreme soil compaction and related infiltration inhibition during irrigation issues, but the relative growth was similar to other states. Trees at $\mathrm{WV}$ were plagued with persistent deer browsing damage, resulting in resprouting from below grafts. Thus, data from WV were not included in any analysis or figure comparing cultivar growth.

Increased $\mathrm{dbh}$ and height are good indicators of root growth and overall suitability for specific growing conditions. Overall cultivar dbh performance varied with some cultivars, like the Asian selection 'JFS Bieberich' elm growing only $41 \%$ $(0.7 \mathrm{~cm} /$ year $\mathrm{dbh})$ of the growth of New Horizon $(1.7 \mathrm{~cm} /$ year dbh) (Figure 3). American cultivars performed similarly to Asian hybrids (Figure 3). Height growth by cultivars generally paralleled diameter growth as most of the tallest plants also had the largest diameter growth. Substantial departures were 'New Harmony' and 'Lewis \& Clark' elms, which had relatively small $\mathrm{dbh}$ for their height, and 'Prospector' and 'Morton Stalwart' elms, which had relatively large $\mathrm{dbh}$ for their height. The fastest height growth was found with the American elm cultivars 'New Harmony' and 'Princeton' ( 0.63 and $0.61 \mathrm{~m}$ /year, respectively) (Figure 4). Crown width growth rates were taken at nine of the sixteen locations, and the variation among cultivars ranged from 0.2 to $0.5 \mathrm{~m} /$ year (Figure 5). Most Asian and European cultivars had greater crown width growth rates than the American elm cultivars,

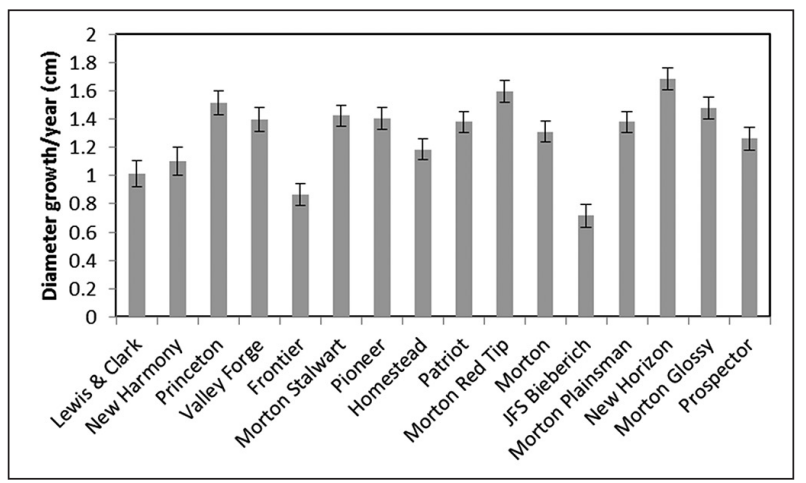

Figure 3. Elm cultivar trunk diameter growth (dbh) per year (cm) with standard-error bars, U.S. National Elm Trial 20052015. Least square means were adjusted to account for variation across sites (states). except for 'Valley Forge', which was similar to the widest Asian cultivar, 'Morton Plainsman'. This result was not surprising considering 'Princeton' and 'New Harmony' American elms are known for their rather narrow growth habit. Conversely, 'Valley Forge' American elm is known for its broad spreading growth as a young tree. 'Frontier' and 'JFS Bieberich' elms had the least crown width growth per year. They also had the least height growth per year (Figure 4). These data suggest that in this trial, these two cultivars either lacked vigor or were slower-growing trees. This was somewhat surprising since the authors have witnessed individual trees of each cultivar growing vigorously and healthily on several independent occasions. 'New Harmony' American elm had a similar crown width growth rate but had the greatest height growth rate, suggesting it has good vigor but a narrow growth form.

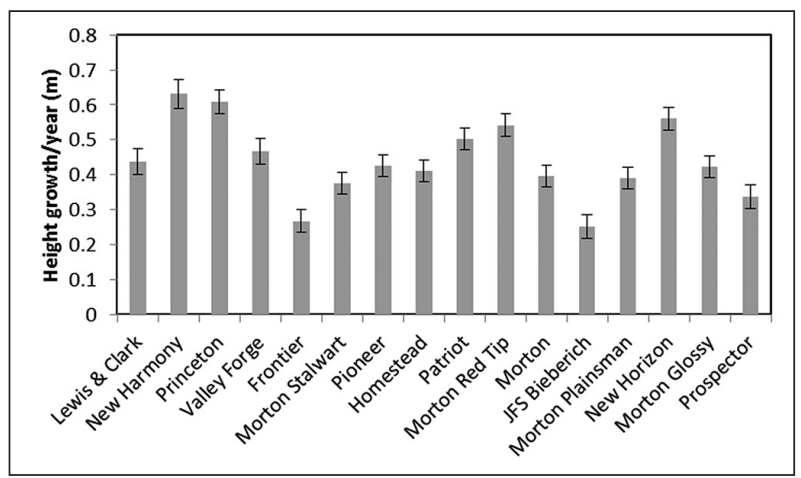

Figure 4. Elm cultivar height growth per year (m) with standard-error bars, U.S. National Elm Trial 2005-2015. Least square means were adjusted to account for variation across sites (states).

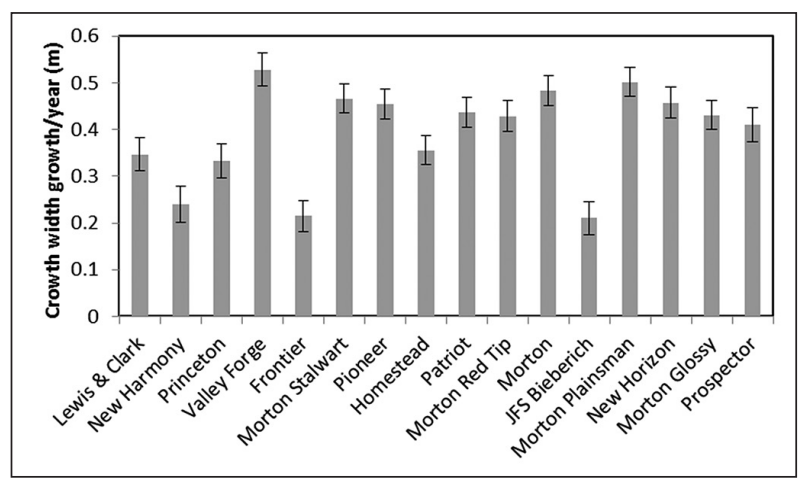

Figure 5. Elm cultivar crown width growth per year $(\mathrm{m})$ with standard-error bars, U.S. National Elm Trial 2005-2015. Least square means were adjusted to account for variation across sites (states). 


\section{Cultivar Form and Autumn Color}

Most cultivars started growing in oval or vase shapes, but some had irregular shapes that became more defined over the 10 years of the study (Table 5). Some elms produced excessive terminal growth within three years of planting. This growth can negatively impact tree architecture and aesthetics. Pruning of elms during their early growth period can encourage a more pronounced vase or oval crowns and prevent excessively long branch growth. Some cultivars commonly have structural defects that need to be corrected with pruning while trees are young. Consulting a certified arborist or other knowledgeable green-industry professional is recommended prior to selecting a specific cultivar of elm.

Autumn color is not a significant ornamental feature of most elms. During this trial, there was usually a period in the autumn season in which most elms produced green/yellow fading to yellow or yellow-brown color. 'Frontier' elm is known for producing some purple/red autumn color. This is rare among elms, and is one of the most notable attributes of the 'Frontier' elm (Table 5).

\section{Cultivar Insect and Disease Issues}

Insect defoliators and scales caused the most obvious damage to trees across trial sites. There were also reports of some damage from foliar fungal diseases, stem cankers, and bacterial wet wood (Figure 6; Figure 7). The common foliar and twig insects included the Japanese beetle (Popillia japonica), European elm flea weevil (Orchestes alni), elm leafminer, European elm scale (Gossyparia spuria), and woolly elm aphid (Eriosoma americanum). At the MI trial site, insect defoliation was the major damage to elms, with Japanese beetle causing $60 \%-75 \%$ of the defoliation, and European elm flea weevil the remainder, depending on the cultivar (see MI report, CSU 2017). No cultivar was considered unacceptable at MI based on insect defoliation, except possibly 'Homestead', which sustained $40 \%$ defoliation. Cooperators in Kentucky (KY) have previously reported on the amount of damage from insect defoliators on the cultivars (Condra et al. 2010; Potter and Redmond 2013). In KY, some cultivars, such as 'Morton', had more than $50 \%$ defoliation by Japanese beetle, but minor defoliation by other insects, while 'Homestead' and 'Pioneer' were impacted by both Japanese beetle and European elm flea weevil. The KY site found the cultivars of Asian species U. parvifolia and $U$. propinqua to be the most resistant to insect defoliators. However, based on the analysis over all National Elm Trial sites, no cultivar was sufficiently damaged by foliar insects to an extent making it unacceptable for landscape planting.

Table 5. Growth form, fall color, and preference ranking of elms in the U.S. National Elm Trial at each trial site.

\begin{tabular}{|c|c|c|c|c|c|c|c|c|c|c|c|c|c|c|c|c|c|c|c|}
\hline \multirow[t]{2}{*}{ Cultivar name } & \multirow[t]{2}{*}{ Form } & \multirow{2}{*}{$\begin{array}{l}\text { Autumn } \\
\text { color }\end{array}$} & \multicolumn{3}{|c|}{ Western states } & \multicolumn{6}{|c|}{ Central states } & \multicolumn{7}{|c|}{ Eastern states } & \multirow[t]{2}{*}{ Total } \\
\hline & & & WA & $\mathrm{CO}$ & $\overline{K S}$ & IA & $\mathrm{NDF}^{z}$ & $\mathrm{NDB}^{\mathrm{y}}$ & $\mathrm{MN}$ & MI & IN & $\mathrm{AL}$ & NY & $\mathrm{NJ}$ & VT & $\mathrm{OH}$ & WV & $\mathrm{KY}$ & \\
\hline \multicolumn{20}{|l|}{ American selections } \\
\hline 'Lewis \& Clark' & vase & yellow/green & & & & & & & & & & & & & & & & & 0 \\
\hline 'New Harmony' & oval & yellow/orange & & $\mathrm{x}^{\mathrm{x}}$ & $\mathrm{x}$ & & & & & $\mathrm{x}$ & & & & & $\mathrm{x}$ & & & & 4 \\
\hline 'Princeton' & vase & yellow & & & $\mathrm{x}$ & & $\mathrm{x}$ & & $\mathrm{x}$ & $\mathrm{x}$ & & & & $\mathrm{x}$ & $\mathrm{x}$ & & & & 5 \\
\hline 'Valley Forge' & vase & yellow/brown & $\mathrm{x}$ & & & & & & $\mathrm{x}$ & & & & & & & & $\mathrm{x}$ & $\mathrm{x}$ & 3 \\
\hline \multicolumn{20}{|l|}{ Asian selections } \\
\hline 'Frontier' & vase & $\mathrm{red} /$ purple & & & & & & & & & & & & $\mathrm{x}$ & & & & & 1 \\
\hline 'Morton Stalwart' & vase & yellow & $\mathrm{x}$ & $\mathrm{x}$ & & $\mathrm{x}$ & & & & & & $\mathrm{x}$ & $\mathrm{x}$ & $\mathrm{x}$ & & $\mathrm{x}$ & & $\mathrm{x}$ & 7 \\
\hline 'Pioneer' & vase & yellow/orange & & & & & & & $\mathrm{x}$ & & & & & & $\mathrm{x}$ & $\mathrm{x}$ & & & 3 \\
\hline 'Homestead' & oval & green/yellow & & $\mathrm{x}$ & & & & & & & & $\mathrm{x}$ & & & & & & & 2 \\
\hline 'Patriot' & vase & green/yellow & $\mathrm{x}$ & & & $\mathrm{x}$ & & & $\mathrm{x}$ & $\mathrm{x}$ & $\mathrm{x}$ & & & & $\mathrm{x}$ & $\mathrm{x}$ & & $\mathrm{x}$ & 7 \\
\hline 'Morton' & vase & yellow/brown & $\mathrm{x}$ & $\mathrm{x}$ & $\mathrm{x}$ & $\mathrm{x}$ & & & $\mathrm{x}$ & & & & $\mathrm{x}$ & & $\mathrm{x}$ & $\mathrm{x}$ & & $\mathrm{x}$ & 9 \\
\hline 'Morton Red Tip' & vase & yellow & $\mathrm{x}$ & & $\mathrm{x}$ & & $\mathrm{x}$ & $\mathrm{x}$ & $\mathrm{x}$ & $\mathrm{x}$ & $\mathrm{x}$ & $\mathrm{x}$ & $\mathrm{x}$ & $\mathrm{x}$ & & & & $\mathrm{x}$ & 8 \\
\hline 'Emer I’ & vase & yellow/orange & & $\mathrm{x}$ & & & & & & & & & & & & & & & 1 \\
\hline ‘Emer II’ & oval & yellow/red & & & $\mathrm{x}$ & & & & & & & & & & & & & & 1 \\
\hline ‘BSNUPF’' & oval & yellow/orange & & & & & & & & & & & & & & & & & 0 \\
\hline 'JFS Bieberich’ & vase & green/yellow & & & & & & & & $\mathrm{x}$ & & & & & & & & & 1 \\
\hline 'Morton Plainsman' & vase & yellow & & & & $\mathrm{x}$ & & $\mathrm{x}$ & $\mathrm{x}$ & & & & & & $\mathrm{x}$ & $\mathrm{x}$ & & & 4 \\
\hline 'New Horizon' & oval & green/yellow & & & & & & $\mathrm{x}$ & & & & & $\mathrm{x}$ & & $\mathrm{x}$ & & $\mathrm{x}$ & & 3 \\
\hline 'Morton Glossy' & vase & green/yellow & $\mathrm{x}$ & $\mathrm{x}$ & & $\mathrm{x}$ & & $\mathrm{x}$ & $\mathrm{x}$ & & $\mathrm{x}$ & & $\mathrm{x}$ & $\mathrm{x}$ & $\mathrm{x}$ & $\mathrm{x}$ & & $\mathrm{x}$ & 10 \\
\hline 'Prospector' & vase & yellow/green & & & & & & & & & $\mathrm{x}$ & & & & $\mathrm{x}$ & $\mathrm{x}$ & $\mathrm{x}$ & & 4 \\
\hline
\end{tabular}

${ }^{z}$ Fargo, North Dakota, U.S.

y Bismarck, North Dakota, U.S.

${ }^{x}$ Cultivars with ' $x$ ' indicates the cultivar was a preferred tree at that trial site based on overall ornamental characteristics. 
'Homestead' elm cultivar was the most severely damaged by defoliators over all trial sites (Figure 6). Adult Japanese beetles feeding on leaves can be quite severe, depending on year, location, and cultivar. The cultivars least damaged by Japanese beetle feeding, based on observations in New Jersey (NJ), MI, and KY, included American elms 'Valley Forge', 'Princeton', and 'New Harmony'; and Asian elms 'JFS-Bieberich', 'Prospector,' 'Emer I', 'Emer II', 'BSNUPF', 'New Horizon', and 'Frontier' (data not presented). Based on the detailed data available at state locations, cultivar selection should carefully consider the state findings in addition to the national averages presented here.

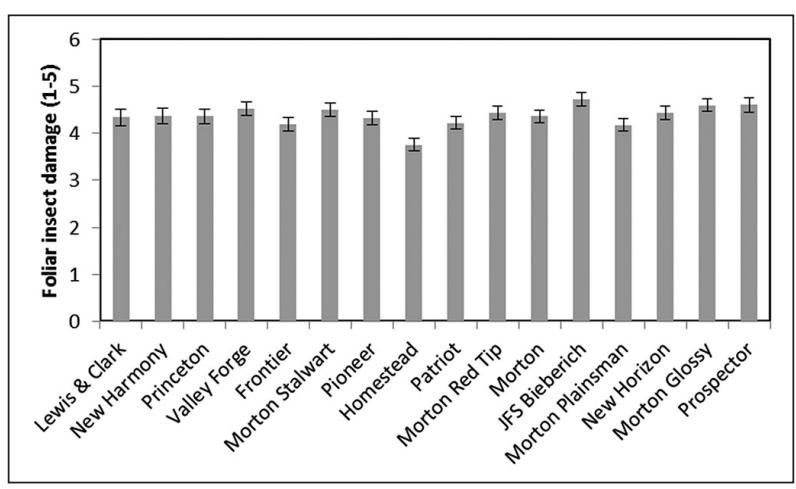

Figure 6. Foliar insect damage rating, with standard-error bars, of elm cultivars, U.S. National EIm Trial 2005-2015 ( 1 = unacceptable; 5 = excellent). Least square means were adjusted to account for variation across sites (states).

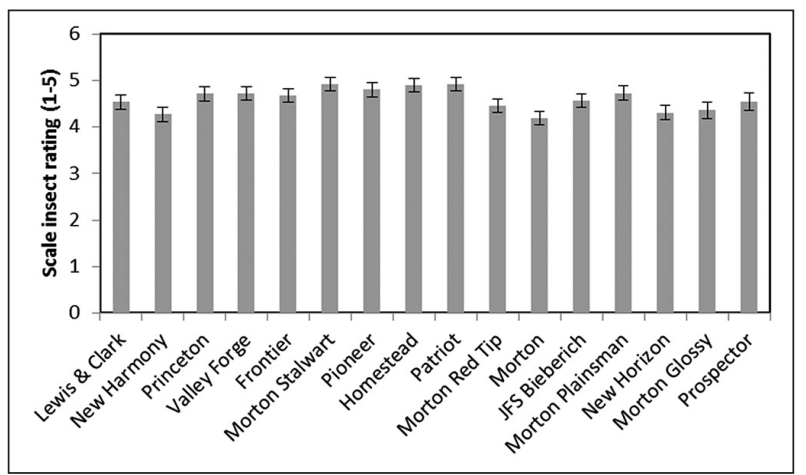

Figure 7. Scale insect rating, with standard error bars, of elm cultivars, U.S. National Elm Trial 2005-2015 (1 = unacceptable; 5 = excellent). Least square means were adjusted to account for variation across sites (states).

Scale insects were a minor issue in most trial locations (avg. rating > 4.2). However, scale populations were higher in $\mathrm{CO}$ and $\mathrm{KY}$ (avg. rating 3.0). In $\mathrm{CO}$, scale insects, primarily European elm scale, caused complete loss of all 'Lewis and Clark' American elm and more than 50\% loss of 'Princeton' American elm. Across all locations, scale insects were most damaging on 'New Harmony', 'Morton', 'New Horizon', and 'Morton Glossy' (Figure 7). In $\mathrm{CO}$, where European elm scale is currently the limiting factor of elms in the urban landscape, 'New Harmony', an American elm, and 'Morton', 'Accolade', 'Morton Stalwart', 'Morton Glossy', 'Morton Red Tip', 'Morton Plainsman', 'Homestead', and 'Prospector' were the most resistant to the insect.

Diseases noted at trial locations included black leaf spot or elm anthracnose (Gnomonia ulmea) at MN, IA, NJ, and NY, as well as bacterial wet wood, DED, and occasional unidentified cankers. DED was noted by the authors on one tree of 'Valley Forge' American elm in New York. The disease was not laboratory confirmed, but identified by the experienced eye of the authors. Although 'Valley Forge' is highly resistant to DED, the tree had been compromised due to significant storm damage that resulted in heavy bark beetle infestation. Abiotic damages that included freeze damage, drought coupled with freeze damage, and wind breakage were noted at several locations. These abiotic stressors likely accounted for most of the mortality across the trial sites. No elm phloem necrosis were reported at any of the trial sites.

\section{Individual Cultivar Performance Summary}

The average performance rating of the 16 wellrepresented cultivars, across all states, ranged from 2.7 for 'JFS Bieberich' elm to 4.6 for 'Morton' and 'New Horizon' elm (Figure 8). Interestingly, 'JFS Bieberich' and 'New Horizon' elm had similar survival rates (Table 4) but were on opposite ends of the data for diameter growth (Figure 3), height growth rate (Figure 4), and canopy width (Figure 5). Data collectors may have favored the rapid growth rate of 'New Horizon' elm. Fifty-six percent of the cultivars performed well and were rated very good $(>4)$, whereas $31 \%$ were rated good $(3-4)$ and $13 \%$ were rated fair to poor $(<2)$ (Figure 8$)$. Cultivars ranking with an average rating of 3 or less should be subject to careful scrutiny as a landscape tree, depending on how they performed within the region. It should be noted that each site had their own evaluator. Therefore, some portion of the variability in cultivar performance 
is likely due to individual evaluator preference or bias, as well as tree cultivar. Based on the ratings, there was not a significant difference among these best performers, including the American elm cultivars 'New Harmony' and 'Princeton', and the Asian elm cultivars, including all of The Morton Arboretum's introductions and 'New Horizon'. Lacebark elm cultivars 'BSNUPF', 'Emer I', and 'Emer II' had poor survival and performance rankings, most likely due to lack of cold hardiness. Based on these observations, lacebark elms would not be recommended in northern locations until more cold-hardy selections are found.

Based on the favorite choices by cooperators, the American elm cultivars 'Princeton' and 'New Harmony' were the best choices, and of the Asian elm cultivars 'Morton Glossy', 'Morton Stalwart', 'Morton', 'Morton Red Tip', and 'Patriot' were the most common favorites (Table 5). Interestingly, all selections from The Morton Arboretum have members of the David elm ( $U$. davidiana) complex (U. japonica, U. wilsoniana, and $U$. propinqua) within their parentage. Based on performance and evaluator preference, this data suggests elm breeding programs should incorporate David elm into their work. It is also worth noting that although decades of efforts to find DED-resistant American elms have been successful, the Asian hybrid elms seem to be favored over the American elms. The authors note that the more restrained growth and the darker green leaves of the Asian hybrids may lead to a more desirable ornamental appearance.

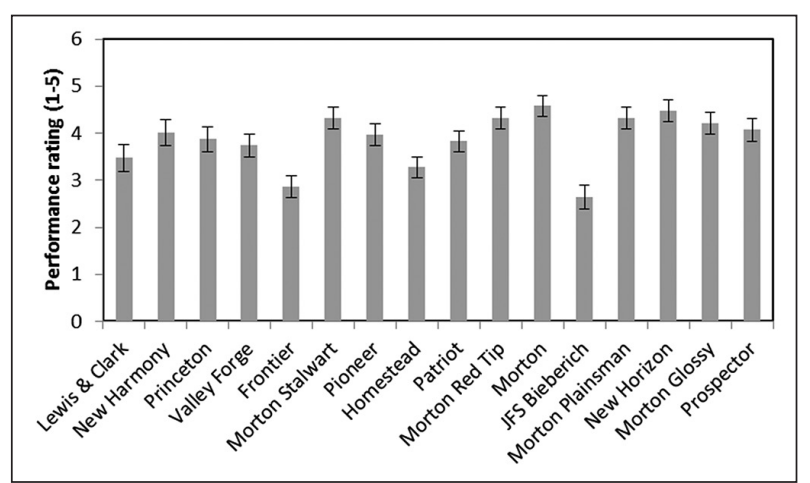

Figure 8. Overall cultivar performance rating, with standarderror bars, of elm cultivars ( 1 = unacceptable; 5 = excellent), U.S. National Elm Trial 2005-2015. Least square means were adjusted to account for variation across sites (states).

\section{CONCLUSIONS}

This study determined, as expected, that growth and horticultural performance of commercially available DED-resistant elm cultivars was different across the various growing conditions and climate regimes of the United States. The variations in soil condition, moisture, temperature, and maintenance precludes any speculation on performance by region of the United States. However, all locations had adequate tree growth to sufficiently evaluate their characteristics and potential landscape uses. Careful selection of elms based on hardiness zones, growth characteristics, and insect resistance/tolerance is critical for future urban tree plantings. Selecting cultivars on overall performance should be tempered with tolerance to insect and disease pressure.

The overall survival data present the best picture of each cultivar's ability to flourish under various conditions. Ranking of disease and insect damage gives a general overview of how the cultivars performed under pest pressure. Since local disease and insect pressure were different at each location, arborists should consult the National Elm Trial website for local performance and resistance data. Unfortunately, at most locations, the actual cause of mortality was undetermined.

Acknowledgments. We appreciate the technical assistance by Keith Warren and Guy Meacham, J. Frank Schmidt Nurseries; statistical assistance by J. zumBrunnen, Franklin A. Graybill Statistical Laboratory, Colorado State University; and Figure 1 by Darci Paull, Kansas Forest Service. We acknowledge the suggested improvements to the manuscript by anonymous reviewers. Trees were donated by the J. Frank Schmidt and Son Co. nursery and other nurseries, and funding to produce the website and complete the study was provided by the J. Frank Schmidt Family Charitable Foundation and the Colorado State University, Agricultural Experiment Station. We greatly appreciate all the work to plant, maintain, and collect data by volunteer cooperators, student volunteers, local arborists, and university staff around the country.

\section{LITERATURE CITED}

American Horticultural Society (AHS). 2017. AHS Plant Heat Zone Map. Accessed 10 May 2016. <http://ahsgardening.org/ gardening-resources/gardening-maps/heat-zone-map>

Colorado State University (CSU). 2017. National Elm Trial. $<$ http:bspm.agsci.colostate.edu/national-elm-trial>

Condra, J.M., C.M. Brady, and D.A. Potter. 2010. Resistance of landscape-suitable elms to Japanese beetle, gall aphids, and leaf miners, with notes on life history of Orchestes alni and Agromyza aristata in Kentucky. Arboriculture \& Urban Forestry 36:101-109.

Costello, L.R., S.R. Scott, and C.M. Drake. 2004. A 10-year evaluation of the performance of four elm cultivars in California, U.S. Journal of Arboriculture 30(2):114-122. 
Dirr, M.A. 2009. Manual of Woody Landscape Plants: Their Identification, Ornamental Characteristics, Culture, Propagation and Uses, sixth edition. Stipes Publishing, Champaign, Illinois, U.S. $1164 \mathrm{pp}$.

Gerhold, H.D., W.N. Wandell, and N.L. Lacasse (Eds.). 1993. Street Tree Factsheets. The Pennsylvania State University.

Harlow, W.M., E.S. Harrar, J.W. Hardin, and F.M. White. 1991. Textbook of Dendrology: Covering the Important Forest Trees of the United States and Canada, seventh edition. McGraw-Hill, New York, New York, U.S. 240 pp.

Karnosky, D.F. 1982. Double jeopardy for elms: Dutch elm disease and phloem necrosis. Arnoldia 42(2):70-77.

Lanier, G.N. 1981. Behavior-modifying chemicals in Dutch elm disease vector control. pp. 371-394. In: Proceedings of the Dutch Elm Disease Symposium and Workshop, 5-9 October 1981, Winnipeg, Manitoba, Canada. Manitoba Department of Natural Resources, Forest Protection and Dutch Elm Disease Branch, Winnipeg, Manitoba, Canada.

Martin, D. 2012. Pest alert: Elm yellows. USDA Forest Service. Northeastern Area State and Private Forestry.

McPherson, G., L. Costello, J. Harding, S. Dreistadt, M.L. Flint, and S. Mezger. 2009. National Elm Trial: Initial report from northern California. Western Arborist. pp. 32-36.

Mittempergher, L., and A. Santini. 2004. The history of elm breeding. Investigación Agraria: Sistemas y Recursos Forestales 13(1):161-177.

NOAA. 2017. NOAA Regional Climate Centers. <http://xmacis. rcc-acis.org>

Peacock, J.W. 1981. Citywide mass trapping of Scolytus multistriatus. pp. 406-426. In: Proceedings of the Dutch Elm Disease Symposium and Workshop, 5-9 October 1981, Winnipeg, Manitoba, Canada. Manitoba Department of Natural Resources, Forest Protection and Dutch Elm Disease Branch, Winnipeg, Manitoba, Canada.

Plotnik, A. 2000. The Urban Tree Book: An Uncommon Field Guide for City and Town. Three Rivers Press, New York, New York, U.S. 54 pp.

Potter, D.A., and C.T. Redmond. 2013. Relative resistance or susceptibility of landscape-suitable elms (Ulmus spp.) to multiple insect pests. Arboriculture \& Urban Forestry 39:236-243.

Riffle, J.W., and G.W. Peterson (tech. coords.). 1986. Diseases of trees in the Great Plains. Gen. Tech. Rep. RM-129. Fort Collins, Colorado, U.S. USDA Forest Service, Rocky Mountain Forest and Range Experiment Station. 96 pp.

Santamour, F.S., and S.E. Bentz. 1995. Updated checklist of elm (Ulmus) cultivars for use in North America. Journal of Arboriculture 21(3):122-131.

Sinclair, W.A., and H.H. Lyon. 2005. Diseases of Trees and Shrubs, second edition. Cornell University Press, Ithaca, New York, U.S. 396 pp.

Slavicek, J.M., and K.S. Knight. 2011. Generation of American elm trees with tolerance to Dutch elm disease through controlled crosses and selection. pp. 342-346. In: R.A. Sniezko, A.D. Yanchuk, J.T. Kliejunas, K.M. Palmieri, J.M. Alexander, and S.J. Frankel (tech coord.). Proceedings of the Fourth International Workshop on the Genetics of Host-Parasite Interactions in Forestry: Disease and Insect Resistance in Forest Trees.

Smalley, E.B., and R.P. Guries. 1993. Breeding elms for resistance to Dutch elm disease. Annual Review of Phytopathology 31:325-352.
Stipes, R.J., and R.J. Campana (Eds.). 1981. Compendium of Elm Diseases. American Phytopathological Society, St. Paul, Minnesota, U.S. 96 pp.

The Morton Arboretum. 2015. Elm cultivars checklist. Accessed 02 December 2015. <http://systematics.mortonarb.org/ulmus>

Townsend, A.M. 2000. USDA genetic research on elms. pp. 271278. In: The Elms: Breeding, Conservation, and Disease Management. C.P. Dunn (Ed.). Kluwer Academic Publishers, Norwell, Massachusetts, U.S.

Townsend, A.M., and L.W. Douglass. 2001. Variation among American elm clones in long-term dieback, growth, and survival following Ophiostoma inoculation. Journal of Environmental Horticulture 19(2):100-103.

Townsend, A.M., and L.W. Douglass. 2004. Evaluation of elm clones for tolerance to Dutch elm disease. Journal of Arboriculture 30(3):179-184.

Townsend, A.M., and L.R. Schreiber. 1975. Recent progress in the breeding and selection of elms. Proceedings of the Central States Tree Improvement Conference 9:1-6.

Townsend, A.M., S.E. Bentz, and L.W. Douglass. 2005. Evaluation of 19 American elm clones for tolerance to Dutch elm disease. Journal of Environmental Horticulture 23(1):21-24.

Townsend, A.M., S.E. Bentz, and G.R. Johnson. 1995. Variation in response of selected American elm clones to Ophiostoma ulmi. Journal of Environmental Horticulture. 13(3):126-128.

USDA. 2012. Plant Hardiness Zone Map. Agricultural Research Service, U.S. Department of Agriculture. <http://planthardiness.ars.usda.gov>

Vega, F.E., and M. Blackwell (Eds.). 2005. Insect-Fungal Associations: Ecology and Evolution. Oxford University Press, New York, New York, U.S. 352 pp.

Webber, J.F., and J.N. Gibbs. 1989. Insect dissemination of fungal plant pathogens of trees. pp. 161-193. In: N. Wilding, NM. Collins, P.M. Hammond, and J.F. Webber. Insect-Fungus Interactions. Academic Press, London, UK.

Jason J. Griffin (corresponding author)

Associate Professor \& Director

Kansas State University

John C. Pair Horticultural Center

1901 E. 95th Street South

Haysville, Kansas 67060, U.S.

jgriffin@k-state.edu

William R. Jacobi

Professor Emeritus

Department of Bioagricultural Sciences and Pest Management

Colorado State University

Fort Collins, Colorado 80523-1177, U.S.

william.jacobi@colostate.edu

E. Gregory McPherson

USDA Forest Service

Pacific Southwest Research Station

Research Forester

1731 Research Park

Davis, California 95618, U.S. 
Clifford S. Sadof

Department of Entomology

901 West State Street

Purdue University

West Lafayette, Indiana 47907-2089, U.S.

James R. McKenna

USDA Forest Service

Northern Research Station

Hardwood Tree Improvement \& Regeneration Center

715 W. State Street

West Lafayette, Indiana 47907-2061, U.S.

Mark L. Gleason

Department of Plant Pathology and Microbiology

351 Bessey Hall

Iowa State University

Ames, Iowa 50011, U.S

Nicole Ward Gauthier

Department of Plant Pathology

University of Kentucky

Lexington, Kentucky 40546-0312, U.S.

nicole.ward@uky.edu

1-859-218-0720

Daniel A. Potter

Department of Entomology

University of Kentucky

Lexington, Kentucky 40546-0091, U.S.

David R. Smitley

Department of Entomology

288 Farm Ln/Rm 243 Nat. Sci. Bldg.

Michigan State University

East Lansing, Michigan 48824 U.S.

Gerard C. Adams

Plant Pathology Department

University of Nebraska-Lincoln

406 Plant Science Hall

Lincoln, Nebraska 68583-0722, U.S.

Ann Brooks Gould

Department of Plant Biology

School of Environmental and Biological Sciences

Rutgers University

Foran Hall/ Cook Campus

59 Dudley $R d$.

New Brunswick, New Jersey 08901, U.S.

Christian R. Cash

Department of Animal and Plant Sciences

State University of New York - Cobleskill

State Rt. 7

Cobleskill, New York 12043, U.S.
James A. Walla

Northern Tree Specialties

2926 Edgemont St. N.

Fargo, North Dakota 58102-1552, U.S.

Mark C. Starrett

Department of Plant and Soil Science

63 Carrigan Drive-Jeffords Hall

The University of Vermont

Burlington, Vermont 05405, U.S.

Gary A. Chastagner

Washington State University

Puyallup Research and Extension Center

Puyallup, Washington 98371, U.S.

Jeff L. Sibley

101 Funchess Hall

Department of Horticulture

Auburn University

Auburn, Alabama 36849, U.S.

Vera A. Krischik

Department of Entomology

University of Minnesota

St. Paul, Minnesota 55108, U.S.

Adam F. Newby

101 Funchess Hall

Department of Horticulture

Auburn University

Auburn, Alabama 36849, U.S. 
Résumé. Ulmus americana (l'orme américain) était un arbre urbain d'importance en Amérique du Nord avant l'introduction du pathogène de la maladie hollandaise de l'orme en 1930. Par la suite, les forêts en milieu urbain et dans les collectivités ont été dévastées par la perte de vastes canopées. Les programmes d'amélioration génétique des arbres ont produit divers cultivars d'ormes américains et eurasiens résistant à cette maladie et les ont rendus disponibles pour la production en pépinières. Cependant, la réception et l'acceptation par les consommateurs ont été lentes. Le National Elm Trial a été mis sur pied afin d'évaluer les taxons d'ormes disponibles commercialement sur le territoire des États-Unis. Établies sur 16 emplacements distincts, la survie et la croissance de ces plantations, ainsi que leur réaction aux maladies et aux insectes ont été observées pendant 7 à 10 ans. L’orme 'Morton' présentait un taux de survie supérieur à $90 \%$, tandis que 13 cultivars montraient des taux de survie variant de $70 \%$ à $90 \%$ tandis que les taux de cinq autres cultivars variaient de $25 \%$ à $69 \%$. La croissance en diamètre du tronc en fonction de la localisation variait de $0,5 \mathrm{~cm} /$ an (Colorado, États-Unis) à plus de 2,0 cm/an (Iowa, États-Unis). Selon les taxons, la croissance en diamètre du tronc variait d'un minimum pour l'orme 'JFS Bieberich' ( $0,7 \mathrm{~cm} / \mathrm{an})$ à un maximum pour l'orme 'New Horizon' (1,7 cm/an). La présence de cochenilles avait des impacts mineurs pour la plupart des emplacements testés, à l'exception du Colorado où les cochenilles ont contribué à la mort de plusieurs cultivars. Les cotes de rendement (échelle de 1 à 5) variaient de 2,7 pour l'orme 'JFS Bieberich' à 4,5 pour l'orme 'New Horizon'. Sur la base des cotes de rendement, les cultivars d'ormes américains préférés étaient le 'New Harmony' et le 'Princeton' tandis que les cultivars favoris d'ormes asiatiques étaient les introductions provenant de l'arboretum Morton et le 'New Horizon'. Ces constatations aideront les professionnels de l'industrie verte à déterminer les cultivars d'orme qui performeront le mieux selon les régions.

Zusammenfassung. Ulmus americana (Amerikanische Ulme) war vor der Einführung des Erregers der Holländischen Ulmenkrankheit im Jahr 1930 ein wichtiger urbaner Baum in Nordamerika. Nachfolgend veränderten sich die urbanen und kommunalen Wälder durch den Verlust von großen Kronenflächen. Baumverbesserungsprogramme produzierten krankheitstolerante Amerikanische und Eurasische Ulmen-Kultivare und führten sie in die Baumschulindustrie ein. Dennoch war die Akzeptanz der Konsumenten sehr niedrig. Ein Nationaler Ulmen-Versuchsanbau wurde zur Bewertung kommerziell erhältlicher Taxa von Ulmen in Amerika etabliert. Nach Etablierung an 16 Standorten wurden bei den Pflanzungen die Überlebensrate und Zuwachs, sowie der Krankheitsdruck und der Befall mit Insekten für 7 bis 10 Jahre überwacht. 'Morton' Ulme hatte $>90 \%$ Überleben, während $13 \mathrm{Kul-}$ tivere $70 \%$ to $90 \%$ erreichten, und fünf Kultivare rangierten vom $25 \%$ bis $69 \%$ Überlebensrate. Der Stammdurchmesserzuwachs pro Standort rangierte von $0.5 \mathrm{~cm} / \mathrm{Jahr}$ (Colorado, U.S.) bis mehr als $2.0 \mathrm{~cm} / \mathrm{Jahr}$ (Iowa, U.S.). Bezogen auf die Taxa rangierten die Stammdurchmesserzuwachsraten von einer niedrigen('JFS Bieberich' Ulme $(0.7 \mathrm{~cm} / \mathrm{Jahr}))$, bis zu einer hohen ('New Horizon' Ulme (1.7 $\mathrm{cm} / \mathrm{Jahr})$ ). Borkenkäfer waren an allen Versuchsstandorten untergeordnete Erscheinungen, bis auf Colorado, wo die Borkenkäfer zum Absterben von einigen Kultivaren beigetragen haben. Eine Bewertung der Performance (auf einer Skala von 1-5) rangierten von 2,7 für die 'JFS Bieberich' Ulme bis hin zu 4,5 für die 'New Horizon'-Ulme. Basierend auf dieser Rangliste waren 'New Harmony' und 'Princeton' die bevorzugten Kultivare der A,merikanischen Ulme und die bevorzugten Kultivare der Eurasischen Ulme waren die Morton Arboretum Einführungen und 'New Horizon'. Diese Ergebnisse werden den Profis der Grünen Industrie helfen können zu bestimmen, welcher Ulmenkultivar an welchem Standort am besten abschneiden wird.
Resumen. Ulmus americana (olmo americano) fue un árbol urbano importante en Norteamérica antes de la introducción del patógeno de la enfermedad holandesa del olmo en 1930. Posteriormente, los bosques urbanos y de la comunidad fueron devastados por la pérdida de grandes doseles. Los programas de mejoramiento de árboles produjeron variedades de olmo americano y eurasiático tolerantes a la enfermedad y las introdujeron en la industria de viveros. Sin embargo, la aceptación del consumidor fue lenta. El Ensayo Nacional del Olmo se estableció para evaluar los taxa comercialmente disponibles del olmo a través de los Estados Unidos. Establecidas en 16 lugares, estas plantaciones monitorearon la supervivencia y el crecimiento, así como la enfermedad y la presión de los insectos durante 7 a 10 años. El olmo 'Morton' tuvo una supervivencia de $>90 \%$, mientras que 13 cultivares promediaron entre un $70 \%$ y un $90 \%$, y cinco cultivares variaron entre un $25 \%$ y un $69 \%$ de supervivencia. El crecimiento del diámetro del tronco por ubicación varió de $0,5 \mathrm{~cm} /$ año (Colorado, EE.UU.) a más de 2,0 $\mathrm{cm} /$ año (Iowa, EE.UU.). Por taxa, el crecimiento del diámetro del tronco osciló entre un mínimo, por JFS Bieberich $(0,7 \mathrm{~cm} /$ año) a uno alto para el olmo New Horizon (1,7 cm / año). Insectos de escama fueron problemas menores en la mayoría de los lugares de ensayo, excepto Colorado, donde las escamas contribuyeron a la muerte de varios cultivares. Las calificaciones de desempeño (escala 1 a 5) oscilaron entre 2,7 para JFS Bieberich 'elm a 4,5 para' New Horizon 'elm. De acuerdo con las calificaciones, los cultivares preferidos de olmo americano fueron 'New Harmony' y 'Princeton', y los cultivares preferidos de olmo asiático fueron las introducciones The Morton Arboretum y 'New Horizon'. Estos hallazgos ayudarán a los profesionales de la industria verde a determinar qué cultivares de olmo se desempeñarán mejor en diferentes regiones. 